\title{
A FORÇA COISA JULGADA EM NOSSO ORDENAMENTO JURÍDICO E ALGMAS CONSIDERAÇÕES SOBRE TAL INSTITUTO NO NOVO CÓDIGO DE PROCESSO
} CIVIL

Caroline Kaizer Lopes ${ }^{1}$

Ivone Juscelina de Almeida ${ }^{2}$

\section{RESUMO}

Esse trabalho gira em torno do instituto da coisa julgada, que está previsto em nossa Constituição (artigo 5ํ, XXXVI) como direito e garantia fundamental, sendo imprescindível à própria existência do discurso jurídico e, elemento estruturante do Estado Democrático de Direito. Há pela doutrina uma enorme divergência acerca da relativização da coisa julgada, dessa forma, serão apresentados os principais pontos conflitantes existentes, levando-se em conta que a mitigação da coisa julgada é uma exceção a regra, ocorrendo em casos excepcionais. Será demonstrada a força da coisa julgada em nosso ordenamento jurídico. Partindo da previsão legal que a coisa julgada material é desfeita pelo ajuizamento da Ação Rescisória, será apresentada a natureza jurídica da mesma, seu prazo de ajuizamento e, em especial, suas hipóteses de cabimento. Também será abordado o instituto da coisa julgada e a ação rescisória no projeto do novo Código de Processo Civil.

PALAVRAS-CHAVE: COISA JULGADA. DIREITO E GARANTIA CONSTITUCIONAL. SEGURANÇA JURÍDICA. DECISÃO JUDICIAL. AÇÃO RESCISÓRIA.

\footnotetext{
${ }^{1}$ Graduada em Direito pelas Faculdades Integradas Vianna Júnior.

${ }^{2}$ Graduada em Psicologia pelo Centro de Ensino Superior de Juiz de Fora (2002), graduação em Direito pela Faculdade de Ciências Jurídicas e Sociais Vianna Júnior (2002) e mestrado em Direito pela Universidade Gama Filho (2006). Atualmente é Coordenadora do Núcleo de Prática Jurídica das Faculdades Integradas do Vianna Junior, professora de processo Civil II, III e IV das Faculdades Vianna Junior e professora de Teoria Geral do Processo do Instituto Metodista Granbery.
} 
Revista das Faculdades Integradas Vianna Júnior

\section{VIANNAS SAPIENS}

edição especial

Juiz de Fora - 2014

\section{INTRODUÇÃO}

É sabido que o instituto da coisa julgada deve ser sempre protegido, a fim de proporcionar segurança e estabilidade às decisões judiciais. No entanto, há hipóteses que a própria lei prevê a relativização da coisa julgada, que ocorre por meio da ação rescisória.

Nessa ordem de idéias, foram apresentadas as possibilidades clássicas de cabimento da ação rescisória, bem como as conjecturas atuais envolvendo seu manejo.

No estudo em tela, analisa-se a força e a importância da coisa julgada no processo civil brasileiro e, a elucidação de alguns aspectos principais da ação rescisória propriamente dita, bem como a não admissibilidade da ação rescisória como forma de relativizar a coisa julgada em casos não previstos em nosso ordenamento jurídico.

O novo Código de Processo Civil propõe a ampliação dos limites objetivos da coisa julgada, vez que conforme a Exposição de Motivos do anteprojeto do novo Código de Processo Civil no seu item 4 destaca que "O novo sistema permite que cada processo tenha maior rendimento possível. Assim, e por isso, estendeu-se a autoridade da coisa julgada à questões prejudiciais".

A ação rescisória representa o único meio legal próprio de desconstituir uma sentença que já transitou em julgado e está revestida da autoridade da coisa julgada material. Possui características próprias e natureza processual de ação, eis que tramitará de forma autônoma. É imprescindível sua importância no sistema processual vigente, em razão da sua finalidade de expurgar da decisão judicial até então definitiva os vícios graves que possui. O novo Código de Processo Civil mantêm suas principais feições, quer do ponto de vista dos fundamentos rescisórios, quer em relação ao seu procedimento.

Por certo, o presente estudo não visa a esgotar e, tampouco encerrar os debates sobre o tema, eis que como vivemos em uma sociedade caracterizada pela rápida transformação de costumes, pensamentos, ideais, objetivos, não há nada que seja absoluto e eterno. 
1 COISA JULGADA

O processo como instrumento de aplicação das normas e princípios possui um rito a ser seguido, ou seja, um procedimento, que variará para cada caso. Esse procedimento a ser seguido possui fases, das quais haverá o momento em que caberá ao magistrado prolatar uma sentença procedente, improcedente ou parcialmente procedente.

Conforme estabelece o artigo 513 do CPC, contra sentença cabe apelação, logo a parte vencida da demanda poderá interpor uma apelação que será apreciada em instância superior, valendo-se do duplo grau de jurisdição consagrado pelo nosso sistema jurídico. Durante o prazo para a interposição dos recursos ou enquanto os mesmos não forem decididos, a sentença apresenta-se apenas como um ato judicial, ato este proferido pelo magistrado tendente a traduzir a vontade da lei em determinado caso concreto. No entanto, os recursos não são infinitos, chegará um momento em que não caberá mais nenhuma modalidade recursal para aquela decisão, o que acarretará o trânsito em julgado da mesma.

Nesse sentido, Humberto Theodoro Júnior (2010, p. 534) leciona:

Para todo recurso a lei estipula prazo certo e preclusivo, de sorte que, vencido o termo legal, sem manifestação do vencido, ou depois de decididos todos os recursos interpostos, sem possibilidade de novas impugnações, a sentença torna-se definitiva e imutável.

Também, Rosana Tosti Rizzato (2012, p. 64) afirma:

$O$ instituto da coisa julgada ou bem julgado, que tem sua derivação originária do latim res iudicata, significa que, uma vez prolatada a sentença, todo seu conteúdo e seus efeitos ficam adstritos aos princípios da imutabilidade e itangibilidade, tornando-a uma decisão imune aos recursos.

Assim uma decisão que transitou em julgado torna-se a princípio imutável e indiscutível, eis que não comportará mais recursos e, tampouco poderá ser 
Revista das Faculdades Integradas Vianna Júnior

\section{VIANNASAPIENS}

edição especial Juiz de Fora - 2014

discutida novamente, consagrando os princípios constitucionais da coisa julgada e da segurança jurídica.

Coqueijo Costa (2002, p. 54) leciona acerca do assunto:

A coisa julgada é uma ficção constitucional-processual que visa à segurança das relações jurídicas, uma verdadeira exigência de ordem social, política, prática, necessária para dar solução a situações de incerteza, devendo prevalecer uma destas, a fim de que haja certeza nas relações jurídicas.

Igualmente, Berenice Soubhie Nogueira Magri (2004, p. 40) afirma:

A finalidade que se alcança através da coisa julgada é a pacificação social, a conciliação dos conflitos de interesses mediante disciplina prévia como consectário da justiça. É a exigência da paz social (...), que visa a estancar definitivamente a discussão do mérito da causa.

A coisa julgada está consagrada na Carta Magna, no artigo 5o, inciso $\mathrm{XXXVI}$, como direito e garantia fundamental, está intimamente relacionada com os institutos do direito adquirido e ato jurídico perfeito, consagrando os princípios constitucionais da segurança jurídica e da certeza jurídica. Ressalte-se que a coisa julgada prevista na $\mathrm{CF} / 88$, não pode ser abolida por emenda constitucional, eis que a mesma trata-se de cláusula pétrea, prevista no artigo

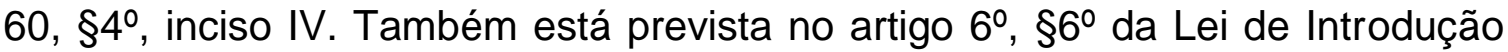
às normas do Direito Brasileiro e nos artigos 467 e 468 do CPC.

Nos dizeres do mestre Giuseppe Chiovenda (2000, p. 452), a coisa julgada retrata a vontade do Estado, consistindo na simples circunstância da aplicação da lei no caso concreto, vejamos:

A sentença é unicamente a afirmação ou a negação de uma vontade do Estado que garanta a alguém um bem da vida no caso concreto; e só a isto se pode estender a autoridade do julgado; com a sentença só se consegue a certeza da existência de tal vontade e, pois, a incontestabilidade do bem reconhecido ou negado. 
Revista das Faculdades Integradas Vianna Júnior

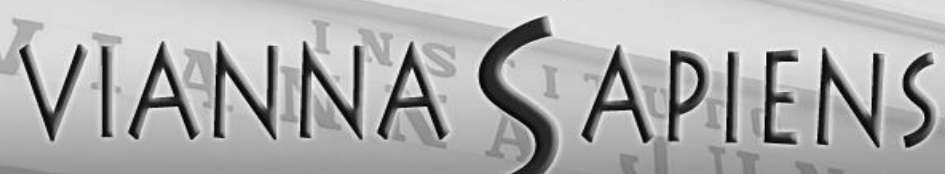

edição especial

Juiz de Fora - 2014

Nesta seara, podemos dizer que o instituto da coisa julgada está ligado a tutela jurisdicional definitiva do Estado-Juiz, cuja decisão proferida passará a ter força de lei entre as partes envolvidas, desempenhando um papel social muito importante, qual seja, assegurando a imutabilidade dos efeitos decorrentes da sentença fora do processo que foi prolatada, o que favorece a parte vencedora, que terá a certeza do direito que lhe cabe.

A coisa julgada está fortemente ligada ao trânsito em julgado, vez que o objeto da lide só se torna imutável e indiscutível quando transitar em julgado, sendo que essa decisão passará a ter força de lei nos limites da lide e das questões decididas.

Importante destacar que a coisa julgada não é um efeito da sentença, mas sim a qualidade dela representada pela imutabilidade do julgamento e de seus efeitos.

O Código de Processo Civil em seu artigo 467 denomina coisa julgada material como: "a eficácia, que torna imutável e indiscutível a sentença, não mais sujeita a recurso ordinário ou extraordinário." Assim, os efeitos da sentença só ocorrerão de forma plena e definitiva quando não for mais suscetível de reforma por meio de recursos.

Conforme já transcrito a cima, o Código de Processo Civil apenas definiu a coisa julgada material como a eficácia da sentença que a torna imutável e indiscutível, não mais sujeita a nenhuma modalidade recursal. No entanto, também existe a coisa julgada formal, que decorre da imutabilidade da sentença, por impossibilidade de interposição de recursos, quando por determinação legal não é mais possível sua interposição, ou quando ocorreu o decurso do prazo, ou também por desistência ou renúncia da parte à sua interposição.

Assim como a coisa julgada formal, a material também decorre da impossibilidade de interposição de recurso contra a sentença. Logo, podemos afirmar que a coisa julgada formal e material, estão relacionadas ao esgotamento das vias recursais ou pela decisão desvantajosa do recurso interposto, o que impossibilita a princípio a realização de quaisquer outros atos processuais tenden- 
tes à alteração da decisão transitada em julgado.

Segundo o Doutrinador Humberto Theodoro Júnior (2010, p. 537):

A coisa julgada formal atua dentro do processo em que a sentença foi proferida, sem impedir que o objeto do julgamento volte a ser discutido em outro processo. Já a coisa julgada material, revelando a lei das partes, produz seus efeitos no mesmo processo ou em qualquer outro, vedando o reexame da res in indicium deducta, por já definitivamente apreciada e julgada.

No mesmo diapasão, Celso Bastos (1994, p. 43) leciona:

(...) o direito incorpora-se ao patrimônio do de seu titular por força da proteção que recebe da imutabilidade da decisão judicial. Daí falar-se em coisa julgada formal e material. Coisa julgada formal é aquela que se dá no âmbito do próprio processo. Seus efeitos restringem-se, pois, a este, não o extrapolando. A coisa julgada material, ou substancial, existe, nas palavras de Couture, quando à condição de inimpugnável no mesmo processo, a sentença reúne a imutabilidade até mesmo em processo posterior.

Dessa forma, com a coisa julgada formal, a decisão se torna imutável dentro do processo, enquanto que com a coisa julgada material, os efeitos da decisão também refletem para fora do processo.

Nesse mesmo sentido, Rosana Tosti Rizzato (2012, p. 64) afirma:

A priori, quando a imutabilidade estiver relacionada com questões internas à relação processual ou endoprocessual, o tema discutido dentro dessa relação jurídica processual não poderá ser rediscutido, formando a coisa julgada formal. Todavia, se a imutabiludade estiver relacionada com questões externas à relação processual ou extraprocessual, a preocupação será com os efeitos refletidos fora do processo, caracterizando a coisa julgada material, lembrando que a coisa julgada formal é um pressuposto indispensável para a coisa julgada material.

Com a coisa julgada material, ocorre a estabilidade da relação jurídica discutida, ou seja, torna-se impossível a rediscussão daquele litígio em outra demanda processual, vez que o dispositivo da sentença que julgou procedente ou improcedente os pedidos do autor, tornou-se imutável e indiscutível, não se sujeitando mais a recurso ordinário ou extraordinário. Logo o juiz não poderá jul- 
Revista das Faculdades Integradas Vianna Júnior

\section{VIANNAS SAPIENS}

edição especial

uiz de Fora - 2014

gar novamente aquele litígio, sempre que uma nova ação tenha as mesmas partes e a mesma causa de pedir.

Ressalte-se que em um determinado caso pode existir apenas a coisa julgada formal, como por exemplo, em sentenças meramente terminativas, as quais apenas extinguem o processo sem adentrarem no mérito. Diferente do que ocorre com a coisa julgada material, eis que para ocorrer a mesma, mister se faz necessária a presença da coisa julgada formal, ou seja, só há coisa julgada material se também existir a formal.

Nesse sentido, sentenças que apenas anulam o processo ou decretam sua extinção pelo artigo 267 do Código de Processo Civil, sem julgar procedente ou improcedente os pedidos autorais, não fazem coisa julgada material, mas apenas formal, eis que produzem efeitos apenas nos limites daquela demanda processual e não fora do processo, o que possibilita a parte autora de ajuizar uma nova ação para discutir a mesma lide.

Também não produzem coisa julgada formal nem material, os despachos de expediente, as decisões interlocutórias, as sentenças proferidas em procedimento de jurisdição voluntária e as decisões proferidas em cautelares, que podem ser modificadas ou revogadas a qualquer momento.

Sendo assim, com exceção dos exemplos a cima, em toda causa o magistrado proferirá uma sentença extinguindo o processo sem julgamento do mérito ou apreciando o mérito, sendo que em qualquer dessas possibilidades ocorrerá a coisa julgada formal, em razão disso, para alguns doutrinadores a coisa julgada formal é o primeiro degrau da coisa julgada material.

É sabido que a coisa julgada é matéria de ordem pública, logo poderá ser argüida em qualquer fase processual. O réu poderá argui-la como preliminar da contestação, conforme preconiza o artigo 301, VI, CPC, no entanto, caso o réu se omita, não ocorrerá preclusão, eis que em razão do interesse ser público, até mesmo o juiz da causa poderá decretá-la de ofício.

Importante salientarmos que a coisa julgada possui limites objetivos e subjetivos, sendo que como limite objetivo temos o dispositivo da sentença, eis que através do mesmo que se encontra o conteúdo decisório do magistrado, lo- 
Revista das Faculdades Integradas Vianna Júnior

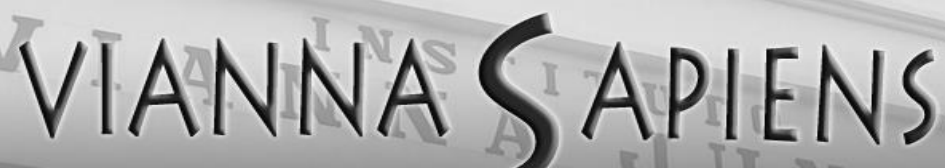

edição especial

Juiz de Fora - 2014

go é atingido pela imutabilidade da decisão. Assim, o artigo 468 do CPC prevê que "a sentença que julgar total ou parcialmente a lide tem força de lei nos limites da lide e das questões decididas." Quanto aos limites subjetivos, temos que a coisa julgada faz lei entre as partes que são alcançadas pela imutabilidade da decisão. Nesse sentido, o artigo 472 do CPC estabelece que "a sentença faz coisa julgada às partes as quais é dada, não beneficiando, nem prejudicando terceiros...".

Assim, o terceiro que não figurou naquela demanda processual não poderá ser atingido pelos efeitos da coisa julgada. Podemos afirmar que a intenção do nosso legislador com o citado dispositivo foi evitar prejuízos ou até mesmo benefícios àqueles que não possuem qualquer relação jurídica com os demandantes.

Humberto Theodoro Júnior (2010, p. 541) leciona acerca do assunto:

A coisa julgada é fenômeno próprio do processo de conhecimento, cuja sentença tende a fazer extinguir a incerteza provocada pela lide instalada entre as partes. Mas fazer cessar a incerteza jurídica não significa apenas fazer conhecer a solução cabível, mas impô-la, tornando-a obrigatória para todos os sujeitos do processo, inclusive o próprio juiz.

Dessa forma, fica claro que a coisa julgada fornece as partes uma certeza jurídica diante da relação controvertida, vinculando as partes e o juiz, ou seja, não será possível restabelecer a mesma controvérsia em outro processo.

A doutrina divide os efeitos da coisa julgada como negativos e positivos. Temos como efeitos negativos a função da coisa julgada de exaurir aquele litígio, impossibilitando uma nova propositura. Já com os efeitos positivos, a coisa julgada determina que às partes envolvidas obedeçam aquela decisão, sendo norma indiscutível entre elas e também obrigando ao magistrado ajustar-se a ela.

Como força vinculativa e impeditiva da coisa julgada, temos que as partes e o juiz não poderão se desvincular dos seus efeitos, que foram consumados no processo de conhecimento. E conforme já dito, caso uma das partes proponha uma mesma demanda processual, ou seja, um processo que contenha as mesmas partes, o mesmo pedido e a mesma causa de pedir, caberá a outra parte 
envolvida argüir em sua contestação coisa julgada, e ao Juiz, até mesmo sem ser provocado quanto a coisa julgada, extinguir o feito sem análise do mérito, conforme artigo 267, V, do CPC.

Humberto Theodoro Júnior (2010, p. 542) conclui:

Portanto, quando o artigo 467 fala em indiscutibilidade e imutabilidade da sentença transitada em julgado refere-se a duas coisas distintas: a) pela imutabilidade, as partes estão proibidas de propor ação idêntica àquela que se estabeleceu a coisa julgada; b) pela indiscutibilidade, o juiz é que em novo processo, no qual se tenha de tomar a situação jurídica definitiva anteriormente pela coisa julgada como razão de decidir, não poderá reexaminá-la ou rejulgá-la; terá de tomá-la simplesmente como premissa indiscutível. No primeiro caso atua a força proibitiva (ou negativa) da coisa julgada, e, no segundo, sua força normativa (ou positiva).

Nesse sentido, podemos concluir que a coisa julgada vincula não apenas as partes envolvidas, mas também o magistrado, eis que caso o mesmo não concorde com a decisão proferida por outro magistrado, não poderá alterá-la, mas somente julgar extinto o feito, sem para tanto analisar o mérito.

Segundo o artigo 471, inciso I, do CPC "se tratando-se de relação jurídica continuativa, sobreveio modificação no estado de fato ou de direito; caso em que poderá a parte pedir a revisão do que lhe foi estatuído na sentença".

Podemos definir relação continuada como aquela que se protrai no tempo, sendo umas das situações de julgamento rebus sic stantibus, ou seja, a sentença dela derivada afeta a teoria da imprevisão, cujos efeitos somente ocorrerão enquanto durarem as circunstâncias que a ensejou.

Nesse contexto, como os fatos e os fundamentos que motivaram aquela decisão poderão ser alterados ou até mesmo não existirem mais, a eficácia da decisão não poderá perdurar imutável e inatingível caso as circunstâncias originais desapareçam ou alterem.

Assim, as decisões que julgam situações que se prolongam no tempo, ficam vinculadas aos acontecimentos futuros que poderão de alguma forma alterar àquela primeira situação jurídica.

Luiz Guilherme Marinoni (2008, p. 144) explica: 
Revista das Faculdades Integradas Vianna Júnior

\section{VIANNA SAPIENS}

edição especial

Juiz de Fora - 2014

O fato de uma relação continuativa poder abrir oportunidade a uma outra ação, diversa da que foi primitivamente proposta, exige que se verifique com cuidado se, na segunda ação, foi alegada uma verdadeira "circunstância nova" ou uma circunstância velha sob roupagem nova.

Dessa forma, deverá sempre ser observado se existe realmente uma nova situação, ou seja, que as circunstâncias mudaram, eis que caso a parte alegue uma circunstância já apresentada, apenas sob um fundamento novo, não há que se falar em revisão da sentença.

Temos como exemplo clássico de uma relação jurídica continuada uma sentença condenatória de alimentos, que perdurará até o momento em que advir situações que a modifiquem, seja por parte do alimentado ou por parte do alimentando. Caso o pai comprove que não é mais viável pagar aquela quantia estipulada pelo juiz, em razão de uma mudança drástica em sua remuneração, estaremos diante de uma possibilidade de revisão do estabelecido naquela decisão.

Essa modificação será objeto de outra ação, qual seja, a ação revisional, que caso seja julgada procedente terá natureza constitutiva, eis que modificará a relação jurídica existente entre as partes daquela demanda inicial de alimentos. No entanto, essa alteração só atuará nas prestações futuras, posteriores a nova situação apresentada, possuindo efeito ex nunc, ou seja, não retroage para as antigas prestações, vez que as mesmas não poderão ser atingidas pela revisão judicial, sob a força da coisa julgada gerada pela anterior sentença.

Ressalte-se que não há que se falar em alteração da sentença anterior, mas sim de obter uma nova sentença para aquela nova situação apresentada.

Nesse sentido o doutrinador Humberto Theodoro Júnior (2010, p. 561) salienta:

Costuma-se identificar o fenômeno da coisa julgada sobre a relação jurídica continuativa com o chamado limite temporal da coisa julgada. Pretende-se, com isso, delimitar, no tempo, a eficácia da sentença dita determinativa, por conseqüência, também, a duração da coisa julgada.

Dessa forma, com o limite temporal, o objeto da sentença desaparece, 
Revista das Faculdades Integradas Vianna Júnior

\section{VIANNASAPIENS}

edição especial

Juiz de Fora - 2014

deixa de existir ou é alterado, fazendo com que àquela decisão não tenha mais sobre o que incidir, por perda do objeto. Assim, caso as mesmas partes venham a discutir em ação revisional, o objeto não será o mesmo, eis que a relação jurídica que deu causa ao litígio não é idêntica a essa segunda possibilidade, vez que os elementos são diferentes. Logo, os efeitos passados daquela decisão estão protegidos pela coisa julgada, não retroagirão.

Quanto ao assunto, já decidiu inúmeras vezes o Tribunal de Justiça de Minas Gerais:

EMENTA: AGRAVO DE INSTRUMENTO - AÇÃO REVISIONAL DE ALIMENTOS - ANTECIPACẼO DE TUTELA - BINÔMIO NECESSIDADE/POSSIBILIDADE - DEMISSÃO - DIMINUIÇÃO DA CAPACIDADE ECONÔMICA DO ALIMENTANTE - Os alimentos, ainda que provisórios, devem respeitar o binômio necessidade/possibilidade. - Os alimentos decorrentes do vínculo de parentesco derivam do dever de sustento entre pais e filhos, se destinam a assegurar ao alimentado o atendimento às suas necessidades essenciais. - A imutabilidade da coisa julgada não atinge a prestação de alimentos que se trata de relação jurídica continuada. - As provas de alteração da capacidade do alimentante autorizam a revisão de alimentos. - A pensão, que representa atualmente $100 \%$ dos rendimentos do genitor, não atende ao princípio da proporcionalidade, pelo que se faz necessária a redução - Recurso desprovido. (AGRAVO DE INSTRUMENTO № 1.0024.08.183494-7/001 - COMARCA DE BELO HORIZONTE - RELATORA: EXM ${ }^{\mathrm{a}}$. DES ${ }^{\mathrm{a}}$ HELOISA COMBAT - DATA DA PUBLICAÇÃO: 03/07/2009).

Também o Egrégio Tribunal de Justiça do Paraná:

EMENTA: APELAÇÃO CÍVEL- AÇÃO DE REVERSÃO DE QUOTAS DE PENSÃO C/C COBRANÇA DE VALORES ATRASADOS COISA JULGADA - INOCORRÊNCIA - RELAÇÃO JURÍDICA CONTINUADA POSSIBILIDADE DE REDISCUSSÃO INTELIGÊNCIA DO ARTIGO 471, INCISO I, DO CÓGIGO DE PROCESSO CIVIL. 1. Ausentes os requisitos legais, não se vislumbra caracterizado o instituto da coisa julgada. 2. Tratando-se de relação passível de modificação no seu estado de fato e de direito, é possível sua rediscussão judicial, a teor do disposto no artigo 471, inciso I, do Código de Processo Civil. 3. Apelação cível provida. (TJ-PR - 8240197 - Data da publicação: 14/02/2012). 
Revista das Faculdades Integradas Vianna Júnior

\section{VIANNA SAPIENS}

edição especial

Juiz de Fora - 2014

Por derradeiro, podemos concluir que nas relações continuadas poderão vir a existir circunstâncias que se alterem com o passar do tempo, o que proporcionará às partes pleitearem a revisão da então decisão prolatada.

\section{A COISA JULGADA NO PROJETO DE LEI DO NOVO CPC}

É sabido que tramita perante a Câmara dos Deputados o Projeto de Lei de ํo 8046/2010 do Senado Federal, que trata do Novo Código de Processo Civil, revogando a Lei o 5.869/1973- atual Código de Processo Civil.

$\mathrm{O}$ atual CPC necessita urgentemente de mudanças, eis que o mesmo já está em vigência há mais de trinta anos, ou seja, entrou em vigor antes mesmo da promulgação da Constituição Federal de 1998. Por isso, a mudança se torna indispensável, vez que o atual CPC não conseguiu acompanhar toda a transformação da sociedade, bem como do Poder Judiciário, nesses últimos trinta anos. O novo diploma traz inúmeras propostas interessantes, é certo que alguns temas clamam por maior reflexão, dentre esses se destaca a ampliação dos limites objetivos da coisa julgada.

O anteprojeto do novo Código de Processo Civil propõe a ampliação dos limites objetivos da coisa julgada, conforme assevera o item de no 4 da Exposição de Motivos do anteprojeto do novo CPC, vejamos "O novo sistema permite que cada processo tenha maior rendimento possível. Assim, e por isso, estendeu-se a autoridade da coisa julgada às questões prejudiciais".

O objetivo da Comissão de Juristas que participaram da elaboração do projeto do novo CPC pode ser visualizado especialmente em três artigos do novo código, que não sofreram quaisquer alterações em seus conteúdos quando da aprovação no Senado Federal, apenas foram alterados em suas numerações.

Importante ser feito um comparativo entre os artigos do CPC atual e do projeto do novo CPC, quanto ao instituto da coisa julgada, vejamos: 
Artigo 5 do CPC atual - Se, no curso do processo, se tornar litigiosa relação jurídica de cuja existência depender o julgamento da lide, qualquer das partes poderá requerer que o juiz a declare por sentença.

Artigo 20 do NCPC - Se, no curso do processo, se tornar litigiosa relação jurídica de cuja existência ou inexistência depender o julgamento da lide, o juiz, assegurado o contraditório, a declarará por sentença, com força de coisa julgada.

Artigo 468 do CPC atual - A sentença, que julgar total ou parcialmente a lide, tem força de lei nos limites da lide e das questões decididas.

Artigo 490 do NCPC - A sentença que julgar total ou parcialmente a lide tem força de lei nos limites do pedido e das questões prejudiciais expressamente decidias.

Artigo 469 do CPC atual - Não fazem coisa julgada:

I - os motivos, ainda que importantes para determinar o alcance da parte dispositiva da sentença;

II - a verdade dos fatos, estabelecida como fundamento da sentença;

III - a apreciação da questão prejudicial, decidida incidentemente no processo.

Artigo 491 do NCPC - Não fazem coisa julgada:

I - os motivos, ainda que importantes para determinar o alcance da parte dispositiva da sentença;

II - a verdade dos fatos, estabelecida como fundamento da sentença.

Analisando os artigos transcritos acima, resta claro que o novo CPC, tem a intenção de extinguir a figura da ação declaratória incidental, abandonando assim o sistema do atual CPC, trazendo uma nova regra, qual seja, o instituto da coisa julgada também compreenderá a questão prejudicial, desde que exista decisão do juiz a respeito da mesma, sem que exista para tanto qualquer pedido das partes. Ocorrendo assim a ampliação dos limites objetivos da coisa julgada.

Ressalte-se que no atual CPC apenas o dispositivo da sentença é coberto pela coisa julgada, enquanto que no novo CPC além do dispositivo, a questão prejudicial decidida pelo magistrado também fará coisa julgada entre as partes.

Temos como exemplo clássico de questão prejudicial a investigação de paternidade em relação aos alimentos, com o novo CPC poderemos afirmar que tal alteração é adequada e prestigia a celeridade processual, vez que evita discussões laterais e futuras demandas.

Dessa forma, pela proposta do Novo CPC, mesmos as questões que não 
Revista das Faculdades Integradas Vianna Júnior

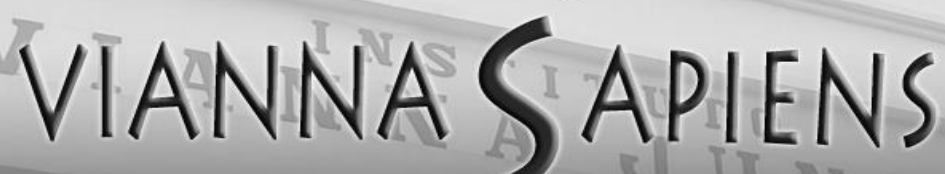

edição especial

Juiz de Fora - 2014

foram muito debatidas no curso do processo em razão de sua pouca relevância, mas que foram brevemente mencionadas na inicial ou na contestação e, foram apreciadas pelo magistrado quando da prolatação da sentença, ainda que de maneira sucinta, poderão ser acobertadas pela coisa julgada.

Urge salientar que isso ocorrerá devido à afirmação feita pelo artigo 490 do novo CPC, que simplesmente determina que as questões prejudiciais que já foram expressamente decididas sejam cobertas pela coisa julgada, deixando de estabelecer qualquer condição quanto ao pedido da parte ou quanto ao grau de cognição. No mais, o referido artigo sequer faz menção à observância do contraditório, mencionando-o apenas no artigo 20.

Assim sendo, para a parte vislumbrar o que será coberto pela coisa julgada em uma decisão judicial, deverá analisar além da parte dispositiva, a parte da fundamentação da decisão, eis que o juiz poderá decidir uma questão prejudicial apenas na fundamentação da sentença e, nos termos do disposto no novo CPC, ainda assim será coberta pela coisa julgada, desde que expressamente decidida.

Dessa forma, provavelmente o grau de insegurança jurídica para as partes e para terceiros aumentará consideravelmente, vez que poderá ser prolatada uma sentença que surpreenda a todos os litigantes

\section{A AÇÃO RESCISÓRIA COMO FORMA DE RELATIVIZAÇÃO DA COISA JULGADA MATERIAL}

Antigamente existia uma enorme controvérsia na doutrina sobre a natureza jurídica da ação rescisória, eis que muitos a comparavam aos recursos, diante das características comuns entre ambos. No entanto, com o passar do tempo, restou consolidado na doutrina e na jurisprudência a distinção entre a ação rescisória e as modalidades recursais.

A ação rescisória possui natureza de ação autônoma de impugnar decisões de mérito transitadas em julgado. Importante destacar que a ação rescisó- 
ria não possui natureza de recurso, eis que só é cabível após o trânsito em julgado, ou seja, após a formação da coisa julgada, e será discutida em processo autônomo. Enquanto que os recursos são interpostos no mesmo processo em que foi proferia a respectiva decisão de mérito e antes do trânsito em julgado da decisão. Assim, podemos afirmar que com a ação rescisória surgirá um novo processo, diverso daquele em que foi prolatada a sentença que será impugnada. Fredie Didier Júnior (2010, p. 359) leciona sobre o assunto:

Ação rescisória não é recurso, por não atender a regra da taxatividade, ou seja, por não estar prevista em lei como recurso. Ademais, os recursos não formam novo processo, nem inauguram uma nova relação jurídica processual, ao passo que as ações autônomas de impugnação assim se caracterizam por gerarem a formação de nova relação jurídica processual, instaurando-se um processo novo. Eis que a ação rescisória ostenta natureza jurídica de uma ação autônoma de impugnação: seu ajuizamento provoca a instauração de um novo processo, com nova relação jurídica processual.

Da mesma forma o professor Ovídio Bapista (2002, p. 472) leciona:

(...) trata-se de uma ação autônoma, que não só tem lugar noutra relação processual, subseqüente àquela onde fora proferida a sentença a ser atacada, como pressupõe o encerramento definitivo dessa relação processual. A ação rescisória (art. 485 do $\mathrm{CPC}$ ), em verdade, é uma forma de ataque a uma sentença já transitada em julgado, daí a razão fundamental de não se poder considerá-la um recurso. Como toda ação, a rescisória forma uma nova relação processual diversa daquela onde fora prolatada a sentença ou o acórdão que se busca rescindir.

Importante destacar que a ação rescisória não possui a pretensão de anular ou invalidar a sentença, mas sim de rescindi-la. A citada ação está prevista no artigo 485 do Código de Processo Civil e possui como objetivo desfazer a coisa julgada material anteriormente formada em outro processo, tratando-se de uma ação constitutiva negativa ou desconstitutiva. O processo formado pela ação rescisória tramitará inicialmente na fase de conhecimento.

Nesse sentido, Vicente Greco Filho (2000, p. 403) aduz:

A ação rescisória é de natureza constitutiva negativa porque 
Revista das Faculdades Integradas Vianna Júnior

\section{VIANNA SAPIENS}

edição especial

Juiz de Fora - 2014

modifica o mundo jurídico desfazendo a sentença transitada em julgado, podendo conter também outra eficácia quando a parte pede novo julgamento em substituição do rescindido.

Nesse diapasão, Berenice Soubhie Nogueira Magri (2004, p. 192) leciona:

Se procedente a ação rescisória, o juízo rescindendo tem natureza constitutiva negativa, porque apaga a sentença do mundo jurídico. Se julgada improcedente a rescisória, a decisão do juízo rescindendo terá natureza de declaratória negativa, no sentido de declarar que o autor não tinha direito à rescisão da sentença e, nesse último caso, o depósito reverterá a favor do réu sem prejuízo do disposto no artigo 20 do CPC. Se julgada procedente a ação rescisória terá natureza declaratória, constitutiva ou condenatória, conforme o caso a ser rejulgado, determinando-se a restituição do depósito (art. 494 do CPC).

Conforme o artigo 485 do Código de Processo Civil, a ação rescisória só será cabível contra sentenças que julgaram o mérito e que já transitaram em julgado, logo, não cabe o ajuizamento de uma ação rescisória contra sentenças meramente terminativas.

José Carlos Barbosa Moreira (2007, p. 95) conceitua ação rescisória como "à ação por meio da qual se pede a desconstituição de sentença transitada em julgado, com eventual rejulgamento, a seguir, a matéria nela julgada".

Dessa forma, caso a ação rescisória seja julgada procedente, terá a força de fazer desaparecer a coisa julgada material, devendo ser novamente analisada e julgada a matéria objeto da sentença que foi rescindida.

Frise-se que como toda a ação, a rescisória deverá preencher os pressupostos processuais e as condições da ação, sendo que além desses requisitos deverá ser observado o prazo de dois anos, contados do trânsito em julgado da sentença que será objeto da rescisória, uma das hipóteses de cabimento previstas no artigo 485 do Código de Processo Civil, e também estarmos sempre diante uma decisão de mérito transitada em julgado, vez que conforme já dito, as sentenças que não julgam o mérito (terminativas), não fazem coisa julgada, podendo a parte ajuizar nova ação.

Quanto às hipóteses arroladas no referido artigo, Nelson Nery Junior 
Revista das Faculdades Integradas Vianna Júnior

\section{VIANNA SAPIENS}

edição especial

Juiz de Fora - 2014

(2006, p. 360) leciona:

As hipóteses que ensejam a rescisão da sentença estão arroladas em numerus clausus na norma ora comentada. Este rol taxativo não admite ampliação por interpretação analógica ou extensiva.

O entendimento citado acima, já está consolidado na Doutrina e na Jurisprudência, vez que tem como fundamento principal a coisa julgada constitucional prevista no artigo 5o, inciso XXXVI, da Constituição Federal.

Nesse sentido, já decidiu o Egrégio Tribunal de Justiça de Minas Gerais:

EMENTA: AÇÃO RESCISÓRIA - ART. 485, CPC - HIPÓTESES TAXATIVAS - INADMISSIIVEL INTERPRETAÇÃO ANALÓGICA OU EXTENSIVA - REEXAME DA PROVA PRODUZIDA E ANALISADA PELO JULGADO RESCINDENDO - NÃO CABIMENTO. As hipóteses que ensejam a rescisão da sentença estão arroladas no art. 485, CPC. Esse rol é taxativo e não admite ampliação analógica ou extensiva. Não cabe ação rescisória para simples reexame de prova produzida e analisada no julgado rescindendo. A rescisória não é recurso ordinário com prazo de dois anos. (Processo: 200000029630000001 MG 2.0000.00.2963000/000(1) - Ministro Relator: Geraldo Augusto - Julgamento: 13/12/2001 - Publicação: 27/02/2002).

Dessa forma, as referidas hipóteses são taxativas, não sendo possível a utilização de interpretação ampliativa ou analógica.

Conforme já dito, a ação rescisória possui como objetivo primordial desconstituir uma decisão que julgou o mérito, transitada em julgado, logo, não cabe o ajuizamento de uma ação rescisória contra uma sentença que não tenha analisado o mérito, ou seja, que tenha sido julgada extinta sem análise do mérito, com base no artigo 267, do CPC.

Vejamos o que o doutrinador Fredie Didier Júnior (2010, p. 362) leciona sobre o assunto:

Mérito, então, é sinônimo de objeto litigioso (composto pelo pedido e pela causa de pedir). Quando o juiz examina o pedido, está a analisar o mérito. Ao acolher ou rejeitar o pedido, o juiz estará julgando o mérito. É por isso que a hipótese contida no inciso do art. 269 do CPC, em razão da qual o processo é extinto com resolução do mérito, quando o juiz acolhe ou rejeita o pedido, caracteriza o típico julgamento do mérito. 
Revista das Faculdades Integradas Vianna Júnior

\section{VIANNA SAPIENS}

edição especial

Juiz de Fora - 2014

Dessa forma, somente será cabível o ajuizamento da ação rescisória contra decisões que já transitaram em julgado e que analisaram os pedidos autorais.

O artigo 487 do CPC prevê os legitimados para proporem a ação rescisória, quais sejam: quem foi parte no processo ou seu sucessor a título universal ou singular, o terceiro interessado e o Ministério Público quando não foi ouvido no processo em que lhe era obrigatória a intervenção ou quando a sentença é o efeito de colusão das parte, a fim de fraudar a lei.

Ressalte-se que quanto ao terceiro interessado, é importante observar que só será legitimado àquele que tiver interesse jurídico e não apenas o meramente de fato.

Nesse sentido, Alexandre Freitas Câmara (2010, p. 23) esclarece:

No que concerne aos terceiros juridicamente interessados, há que se recordar que os terceiros não são alcançados pela autoridade de coisa julgada, que restringe seus limites subjetivos àqueles que foram partes do processo onde se proferiu a decisão. Pode haver, porém, terceiro com interesse jurídico (não com interesse meramente de fato) na rescisão da sentença. Como regra, o terceiro juridicamente interessado será aquele que pode intervir no processo original como assistente. Considera-se, também, terceiro legitimado a propor "ação rescisória" aquele que este já ausente do processo principal, embora dele devesse ter participado na condição de litisconsorte necessário.

O CPC prevê apenas a legitimidade ativa da ação rescisória, sendo omisso quanto à legitimidade passiva. A doutrina majoritária defende que todos que figuraram como parte na demanda inicial, deverão ser citados na forma de litisconsortes necessário.

Assim, Fredie Didier Júnior (2010, p. 370) afirma:

Entende-se que todos os partícipes da relação processual oriunda da ação matriz devem ser citados, como litisconsortes necessários, já que o acórdão que será nele proferido atingirá a esfera jurídica de todos. Se o objeto da ação rescisória só disser respeito a algum ou alguns dos participantes do processo originário, somente esses devem ser citados como litisconsortes necessários, e não todos. 
Revista das Faculdades Integradas Vianna Júnior

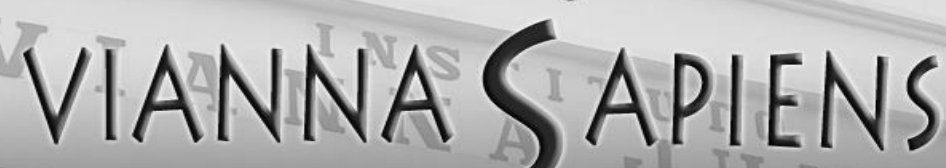

edição especial

Juiz de Fora - 2014

Alexandre Freitas Câmara (2010, p. 24), no mesmo sentido, menciona:

Serão demandados na "ação rescisória" todos aqueles que tenham sido partes do processo original e não figurem já no pólo ativo desta nova relação processual (...). Trata-se de litisconsórcio necessário, o que faz concluir que a presença de todos será essencial para a eficácia da decisão a ser proferida na "ação rescisória".

Quanto ao prazo para ajuizamento da ação rescisória, o CPC em seu artigo 495, prevê o prazo de 2 (dois) anos, contado do trânsito em julgado da decisão.

Importante destacar, que o referido prazo de dois anos também se aplica a Fazenda Pública, eis que a mesma nesse caso não dispõe da prerrogativa conferida pelo artigo 188 do CPC, que lhe confere prazo estendido para contesta e recorrer. $\mathrm{O}$ artigo 495 do CPC deverá ser interpretado de maneira literal para todos, inclusive para a Fazenda Pública.

A doutrina e a jurisprudência já consolidaram o entendimento de que 0 prazo para propositura da ação rescisória é decadencial e não prescricional. Inclusive o Superior Tribunal de Justiça, já sumulou seu entendimento através da Súmula 401, cujo teor é o seguinte: "O prazo decadencial da ação rescisória só se inicia quando não for cabível qualquer recurso do último pronunciamento judicial."

Fredie Didier Júnior (2010, p.379) leciona:

Ora, já se viu que a ação rescisória tem natureza de ação desconstitutiva ou constitutiva negativa. Significa, então, que seu ajuizamento decorre do exercício, pela parte autora, de um direito potestativo à descontituição da coisa julgada. $O$ prazo de seu ajuizamento é, portanto, decadencial. E, sendo assim, não se prorroga, nem se suspende, nem se interrompe.

No mesmo sentido, Humberto Theodoro Júnior (2010, p. 732) conclui:

Não se dá em caráter decadencial, a possibilidade de suspensão ou interrupção do prazo extintivo do direito de propor a rescisória, ao contrário do que ocorre com a prescrição.

Dessa forma, restou claro que o prazo para o ajuizamento da ação resci- 
sória é de dois anos e decadencial, sendo a decadência nesse caso legal, ou seja, prevista em lei, cabendo ao respectivo tribunal apreciar a decadência de ofício, sem ser provocado, nos casos que a rescisória for proposta além do referido lapso temporal.

Conforme súmula do STJ transcrita acima, o início da contagem do prazo decadencial para propositura da ação rescisória só se inicia quando não for cabível qualquer modalidade recursal do último pronunciamento judicial, ou seja, do trânsito em julgado da decisão.

Assim, já decidiu inúmeras vezes o STJ:

PROCESSO CIVIL - RECURSO ESPECIAL - AÇÃO RESCISÓRIA - PRAZO DECADENCIAL - TERMO A QUO. 1. O termo inicial para o ajuizamento da ação rescisória é a data do trânsito em julgado da última decisão da causa, independentemente de o recurso ter sido interposto por apenas uma das partes ou a questão a ser rescindida não ter sido devolvida ao Tribunal. 2. o Trânsito em julgado material somente ocorre quando esgotada a possibilidade de interposição de qualquer recurso. 3. Afasta-se tese em contrário, no sentido de que os capítulos da sentença podem transitar em julgado em momentos distintos. 4. Recurso especial provido. (STJ, $2^{a}$ T., REsp n. 415.586/ DF, rel Min. Eliana Calmon, j. 12/11/2002, publicado no DJ de 09.12.2002, p. 328).

Também, no mesmo sentido, Fredie Didier Júnior (2010, p. 381) leciona:

A partir do trânsito em julgado da decisão final, inicia-se a contagem do prazo para ajuizamento da ação rescisória. Ora, a coisa julgada material opera-se quando a decisão não está mais sujeita a qualquer recurso (CPC, art. 467). De fato, na dicção do § $3^{\circ}$ do art. $6^{\circ}$ da Lei de Introdução ao Código Civil, "chama-se coisa julgada ou caso julgado a decisão judicial de que já não caiba recurso". Em outras palavras, não cabendo mais recurso, haverá então, coisa julgada.

Desta sorte, enquanto todos os recursos interpostos sobre aquela decisão não forem apreciados, não há que se falar em ajuizamento da rescisória, eis que um dos seus requisitos principais é o trânsito em julgado da última decisão dada naquele processo.

O artigo 485 do CPC prevê todas as hipóteses legais para o cabimento da 
ação rescisória, vejamos:

Artigo 485 - A sentença de mérito, transitada em julgado pode ser rescindida quando:

I - se verificar que foi dada por prevaricação, concussão ou corrupção do juiz;

II - proferida por juiz impedido ou absolutamente incompetente;

III - resultar de dolo da parte vencedora em detrimento da parte vencida, ou de colusão entre as partes, a fim de fraudar a lei;

IV - ofender a coisa julgada;

$\mathrm{V}$ - violar literal disposição de lei;

$\mathrm{VI}$ - se fundar em prova, cuja falsidade tenha sido apurada em processo criminal ou seja provada na própria ação rescisória;

VII - depois da sentença, o autor obtiver documento novo, cuja existência ignorava, ou de que não pôde fazer uso, capaz, por si só, de lhe assegurar pronunciamento favorável;

VIII - houver fundamento para invalidar confissão, desistência ou transação, em que baseou a sentença;

IX - fundada em erro de fato, resultante de atos ou de documentos da causa.

E conforme já dito, tais hipóteses são elencadas de forma taxativa, logo, não poderão ser interpretadas de forma analógica.

Sobre o assunto, Alexandre Freitas Câmara (2010, p. 11) esclarece:

As hipóteses de rescindibilidade da sentença são expressamente previstas em lei e devem ser interpretadas restritivamente, uma vez que a possibilidade de ataque à coisa julgada substancial é de todo excepcional. Apenas nos casos previstos no art. 485 do CPC é que se terá como admissível a rescisão da sentença.

Nesse mesmo sentido, Adriane Donadel (2003, p. 104) afirma:

(...) trata-se de enumeração taxativa e exaustiva, não comportando interpretação analógica tendente a aumentar o número de possibilidade de rescisão, pois os casos expressos são hipóteses excepcionais de desfazimento da coisa julgada.

Ainda podemos falar que o referido artigo enumera os possíveis fundamentos da ação rescisória, ou seja, são a causa de pedir a rescisão da decisão que transitou em julgado.

Assim, José Carlos Barbosa Moreira (1989, p. 205):

A cada fundamento típico (não a cada inciso) corresponde uma 
Revista das Faculdades Integradas Vianna Júnior

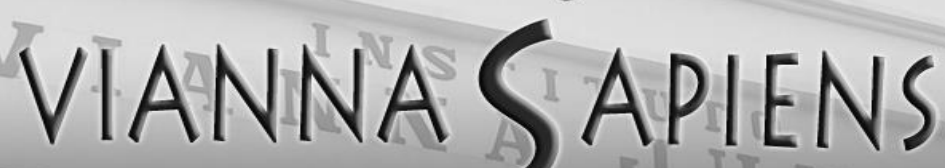

edição especial

Juiz de Fora - 2014

possível causa de pedir. (...) Quando alguém pode a rescisão de sentença com invocação de dois ou mais fundamentos, na realidade está propondo duas ou mais ações cumuladas.

Também nesse sentido, Fredie Didier Júnior (2010, p. 383-384) afirma:

Essa constatação é importante, pois, sendo causa de pedir, questão de fato, o tribunal não pede rescindir a decisão por fundamento não invocado em razão da regra da congruência (art. 128 e art. 460 do $C P C)$.

Importante destacar alguns pontos quanto à hipótese de ajuizamento da ação rescisória quando há ofensa à coisa julgada, prevista no inciso IV do citado artigo.

É sabido que o instituto da coisa julgada material torna a decisão de mérito transitada em julgado, imutável e indiscutível, não podendo as partes ajuizarem nova demanda rediscutindo o mesmo mérito. Essa proibição não é só para as partes, mas também para juiz, eis que o mesmo não poderá desconsiderar a coisa julgada, prolatando nova decisão em um novo processo acerca de idêntica causa de pedir, mesmo que essa nova decisão seja diversa da primeira. A coisa julgada é matéria constitucional, está prevista no título dos direitos e garantias fundamentais, logo, todo o ordenamento infraconstitucional, bem como os aplicadores do direito, deverão sempre respeitá-la. Por isso, uma decisão que desconsidere a coisa julgada material deverá ser rescindida.

Corroborando todo o alegado, Alexandre Freitas Câmara (2010, p. 2010) leciona:

(...) a coisa julgada material impede qualquer nova discussão e decisão a respeito do que ficou coberto por seus limites. É proibida a prolação de qualquer sentença que desconsidere a coisa julgada, pouco importando se a nova sentença tenha conteúdo igual ou diverso da sentença transitada em julgado.

Humberto Theodoro Júnior (2010, p. 715), no mesmo sentir, menciona:

Após o trânsito em julgado, cria-se para os órgãos judiciários uma impossibilidade de voltar a decidir a questão que foi objeto da sentença. Qualquer nova decisão, entre as mesmas partes, violará a intangibilidade da res iudicata. $E$ a sentença, assim ob- 
Revista das Faculdades Integradas Vianna Júnior

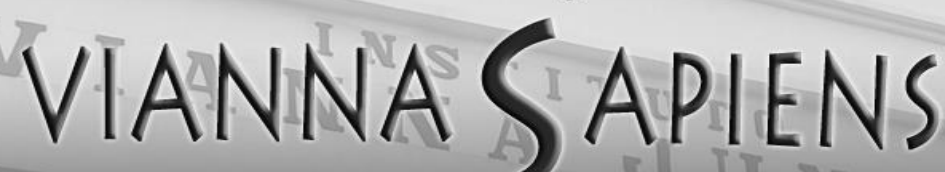

edição especial

Juiz de Fora- 2014

tida, ainda que confirme a anterior, será rescindível, dado o impedimento em que se achava o juiz de proferir nova decisão.

Dessa forma, sentenças que violem a coisa julgada material, serão rescindíveis por força do inciso IV do CPC.

É sabido que o instituto da mitigação da coisa julgada é uma exceção a regra, ocorre em casos excepcionais, quando a justiça prevalece sobre a segurança jurídica. Em regra, a coisa julgada material é desfeita pelo ajuizamento da Ação Rescisória, que conforme já dito, possui natureza de ação autônoma de impugnação contra decisões de mérito que já transitaram em julgado. É de extrema importância para o Direito a preservação da segurança jurídica, contudo, esta segurança poderá ser rescindida quando presentes os pressupostos para o ajuizamento da ação rescisória, podendo assim ocorrer à quebra da coisa julgada.

Existem duas hipóteses mais importantes de relativização da coisa julgada, quais sejam: a relativização da coisa julgada material e da coisa julgada inconstitucional.

$\mathrm{Na}$ atualidade vem sendo muito debatido pelos doutrinadores a possibilidade de desconstituição da coisa julgada sem a utilização da ação rescisória ou em casos que houve o decurso do prazo decadencial de dois anos para o seu ajuizamento. A corrente doutrinária que defende a possibilidade de rediscutir a coisa julgada após o decurso do prazo decadencial de dois anos, salienta que o instituto da coisa julgada não poderia prevalecer sobre a realidade dos fatos, eis que uma decisão injustiça não deveria ser mantida eternamente. Dessa forma, a segurança jurídica passa a ser relativizada em prol da efetividade da justiça.

Nesse sentido, Cândido Rangel Dinamarco (2002, p. 08-09; 22) leciona:

(...) o valor da segurança das relações jurídicas não é absoluto no sistema, nem o é, portanto, a garantia da coisa julgada, porque ambos devem conviver com outro valor de primeiríssima grandeza, que é o da justiça das decisões judiciais, constitucionalmente prometido mediante a garantia do acesso à justiça (CF, art. 5ํ, XXXV). (...) não é legítimo eternizar injustiças a pretexto de evitar a eternização de incertezas. (...). Conclui-se que é 
Revista das Faculdades Integradas Vianna Júnior

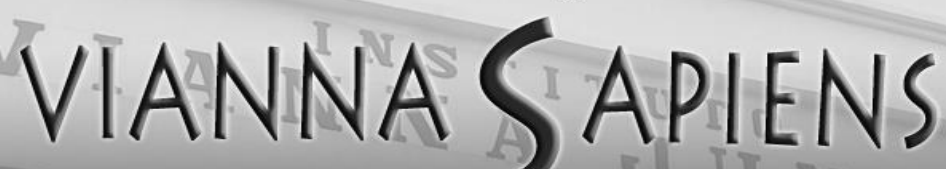

edição especial

Juiz de Fora - 2014

inconstitucional a leitura clássica da garantia da coisa julgada, ou seja, sua leitura com a crença de que ela fosse algo absoluto e, como era hábito dizer, capaz de fazer do preto, branco e do quadrado, redondo.

Igualmente, José Augusto Delgado (2002, p. 2002) alega:

A injustiça, a imoralidade, o ataque à Constituição, a transformação da realidade das coisas quando presentes na sentença viciam a vontade jurisdicional de modo absoluto, pelo que, em época alguma, ela transita em julgado. Os valores absolutos da legalidade, moralidade e justiça estão acima do valor segurança jurídica. Aqueles são pilares, entre outros, que sustentam o regime democrático, de natureza constitucional, enquanto esse é valor infraconstitucional oriunda de regramento processual.

Todavia, a segurança das relações jurídicas deve ser levada em conta, sob pena de desmoronamento da ordem jurídico-social gerando um caos na sociedade. Essa desordem do ordenamento jurídico, certamente, acabaria por afetar o ideal de justiça.

Assim, Ovídio A. Baptista (2002, p. 32) afirma:

A gravidade da injustiça como condição para "confrontar", (...), a coisa julgada acabaria, sem a menor dúvida, destruindo o próprio instituto da res iudicata. (...). Pretender que a coisa julgada seja desconsiderada quando a sentença seja "injusta" não é, seguramente, um ideal da modernidade. (...). Suponho desnecessário sustentar que a "injustiça da sentença" nunca foi e, a meu ver, jamais poderá ser, fundamento para afastar o império da coisa julgada.

Conforme já visto, a ação rescisória tem como fundamento desconstituir a coisa julgada material, ou relativizá-la. No entanto, os Tribunais Superiores vem entendendo que não é possível o ajuizamento da ação rescisória para reformar decisões injustas apenas, que não se enquadram no rol do artigo 485 do CPC, sob o fundamento de que para o ajuizamento da mesma deverá estar presentes algum dos motivos de rescindibilidade dos julgados previstos no rol taxativo do citado artigo. Dessa forma, não há que se falar em ação rescisória quando não existir uma das hipóteses de cabimento.

Exatamente nesse sentido já decidiu o Superior Tribunal de Justiça: 
Revista das Faculdades Integradas Vianna Júnior

\section{VIANNA SAPIENS}

edição especial Juiz de Fora - 2014

AÇÃO RESCISÓRIA. PENSÃO POR MORTE. VIOLAÇÃOA LITERRAL DISPOSIÇÃO DE LEI. ERRO DE FATO. INOCORRÊNCIA. INJUSTIÇA DA DECISÃO. Alegada violação a dispositivo legal que não se refere ao julgado, mas a fato posterior, pertinente à intimação, não autoriza conhecimento pelo inciso $\mathrm{V}$, do artigo 485, do CPC. A ação rescisória constituiu meio excepcional de impugnação, não se prestando a apreciar a justiça, ou injustiça, da decisão rescindenda. Ação julgada improcedente. (Superior Tribunal de Justiça. Ação Rescisória no 1469/PB, Terceira Seção. Relator: Min. José Arnaldo da Fonseca. Brasília, DF, 12 de maio de 2004.)

Dessa forma, podemos afirmar que a ação rescisória somente poderá relativizar a coisa julgada material, quando presentes uma das hipóteses de seu cabimento previstas no artigo 485 do CPC e dentro do prazo decadencial de dois anos, não sendo o meio adequado para relativizar uma decisão injusta, que não se enquadra no rol taxativo das hipóteses de cabimento, ainda que essa injustiça seja de natureza grave.

\section{A ação rescisória no projeto do novo CPC:}

O projeto do novo Código de Processo Civil que está tramitando perante a Câmara dos Deputados - Projeto de Lei de n 8046/2010 do Senado Federal, pretende introduzir o Novo Código de Processo Civil, revogando a Lei 5.869/1973atual Código de Processo Civil, prevê algumas alterações sugeridas pelo substitutivo aprovado pelo Senado Federal quanto à ação rescisória.

Temos como primeira alteração sua localização no Código de Processo Civil. No atual CPC, a ação rescisória está situada no Livro I - Do processo de conhecimento, Título IX - Do processo nos Tribunais e no Capítulo IV - Da ação rescisória, nos artigos 485 a 495 . Enquanto que no projeto do novo CPC, o tema passa a ser regulado no Livro IV - Dos processos nos tribunais e dos meios de impugnação das decisões judiciais, Título I - Dos processos nos tribunais, Capítulo VI - Da ação rescisória e da ação anulatória e na Seção I - Da ação rescisória, nos artigos 919 a 928. 
Revista das Faculdades Integradas Vianna Júnior

\section{VIANNAS SAPIENS}

edição especial

Juiz de Fora - 2014

No atual CPC, a ação anulatória está inserida no mesmo Capítulo que a ação rescisória (Capítulo VI), sendo que no projeto do novo CPC, a ação anulatória é disposta em seção diversa da rescisória. Essa alteração irá facilitar para os aplicadores do direito, tendo em vista que a ação anulatória não possui qualquer relação com a rescisória, sendo diversas as hipóteses que as autorizam, bem como os seus procedimentos.

Comparando o artigo 485 do atual CPC com o artigo 919 do projeto do novo CPC, é possível verificar que com o acréscimo dos acórdãos como objeto da ação rescisória, o seu alcance passou a atingir claramente aos julgamentos colegiados dos tribunais; enquanto que no texto original o legislador só se refere a sentença de mérito como objeto da ação rescisória, vejamos:

Artigo 485, caput - A sentença de mérito, transitada em julgado, pode ser rescindida quando (...).

Artigo 919, caput - A sentença ou acórdão de mérito, transitados em julgado, podem ser rescindidos quando (...).

As hipóteses de ajuizamento da ação rescisória no atual CPC estão previstas em nove incisos do artigo 485, contemplando situações consideradas extremamente excepcionais capazes de afastara a segurança jurídica gerada pelo instituto da coisa julgada material. No projeto do novo CPC, essas hipóteses são preservadas sem quaisquer alterações em sua grande maioria, no entanto, foram introduzidas pequenas mudanças nos fundamentos da ação rescisória previstos nos incisos II, V, VII, VIII e IX do CPC atual.

No que concerne ao prazo para ajuizamento da ação rescisória, o CPC vigente, estabelece em seu artigo 495 o prazo de dois anos, contados do trânsito em julgado da decisão rescindenda. Já o projeto do novo CPC, reduz esse prazo para um ano, contado do trânsito em julgado da decisão, conforme artigo 928 do novo CPC.

Importante destacar que o projeto do novo CPC, adotou a opção de não romper com o sistema vigente, eis que realizou poucas alterações, sem abandonar a linha adotada pelo atual CPC. 
Revista das Faculdades Integradas Vianna Júnior

\section{VIANNA SAPIENS}

edição especial

Juiz de Fora

\section{CONCLUSÃO}

Diante do estudo realizado, pode-se dizer que a coisa julgada pode ser definida como a imutabilidade e indiscutibilidade da sentença de mérito com trânsito em julgado, esses termos estão presentes na definição legal de coisa julgada (artigo 467, do CPC). A Imutabilidade tem como conseqüência a impossibilidade de rediscussão da lide que já foi julgada, acarretando a proibição de propositura de ação idêntica àquela já decidida anteriormente, sendo este o aspecto negativo da coisa julgada. Já a indiscutibilidade, tem a função de fazer com que a conclusão a que anteriormente se chegou com a decisão de mérito, seja observada e respeitada em futuros processos.

A coisa julgada é a grande responsável pela segurança jurídica fornecida às partes pela decisão judicial transitada em julgada. Atribuiu estabilidade para as decisões judiciais, garantindo às partes segurança jurídica; tal instituto proporciona à sociedade a segurança e a certeza acerca de determinado direito, vez que tem o cunho de encerrar e pacificar os litígios instaurados pelas partes. Importante salientar que a coisa julgada não é um efeito da sentença, mas sim a qualidade dela representada pela imutabilidade do julgamento e de seus efeitos.

O novo Código de Processo Civil propõe a ampliação dos limites objetivos da coisa julgada, extinguindo assim a figuração da ação declaratória incidental, trazendo uma nova regra, qual seja, a coisa julgada também abrangerá a questão prejudicial, desde que tenha havido decisão do juiz a respeito da mesma, mesmo que as partes não tenham pleiteado.

Nesse sentido, para verificar o que será coberta pela coisa julgada, também haverá a necessidade de analisar a fundamentação da sentença e, não apenas o dispositivo, como acontece atualmente. Ocorre que essa ampliação poderá trazer uma insegurança para as partes e terceiros envolvidos.

Quanto a ação rescisória, temos que a mesma representa o meio próprio de desconstituir a sentença revestida pela autoridade da coisa julgada material, possuindo características próprias e natureza processual de ação. 
Revista das Faculdades Integradas Vianna Júnior

\section{VIANNA SAPIENS}

edição esp

Juiz de Fora

Frise-se que a ação rescisória é um instrumento processual de notória importância em nosso ordenamento jurídico, sendo o único meio legal, previsto expressamente no Código de Processo Civil, para relativizar a coisa julgada, que durante muito tempo foi tida como absolutamente imutável e indiscutível. Revelase assim um importante veículo para expurgar da decisão judicial transitada em julgado, os vícios graves que possui.

No entanto, nosso legislador se mostrou cauteloso ao estabelecer as hipóteses de cabimento da ação rescisória, tendo em vista que as referidas hipóteses previstas no artigo 485 do Código de Processo Civil fazem parte de um rol taxativo, ou seja, não cabe interpretação extensiva para tais hipóteses, vez que estamos diante de casos de extrema peculiaridade.

Além disso, para evitar flagrante insegurança jurídica e instabilidade social, o legislador estabeleceu o prazo de dois anos para a parte poder se valer da ação rescisória. Quando transcorrido esse lapso temporal, que inicia sua contagem do transito em julgado, a coisa julgada não é mais passível de impugnação. Ressalte-se que esse lapso temporal foi reduzido para um ano no projeto do novo CPC.

De outra banca, tem-se discutido muito a hipótese de relativização da coisa julgada sob o fundamento da existência de grave feita pela decisão de mérito. Contudo, a aceitação da injustiça como fundamento para relativizar decisões transitadas em julgado por meio de ação rescisória, acarretaria um caos ao Poder Judiciário, na medida em que o elemento "injustiça" é caracterizado pela impossibilidade de análise objetiva e imparcial por meio do julgador.

Merece destaque o princípio da segurança jurídica, eis que o mesmo é indispensável para a concretização do Estado de Direito, sendo que a segurança das relações jurídicas deverá ser observada, sob pena de desmoronamento da ordem jurídico-social, o que acarretaria uma desordem na sociedade, especialmente no Judiciário. E esse tumulto no ordenamento jurídico, certamente, acabaria por afetar o ideal de justiça e a concretude do Estado Democrático de Direito.

O princípio da segurança jurídica sempre foi muito defendido em nome da coletividade, tendo em vista que o mesmo corrobora com o caráter de imutabili- 
Revista das Faculdades Integradas Vianna Júnior

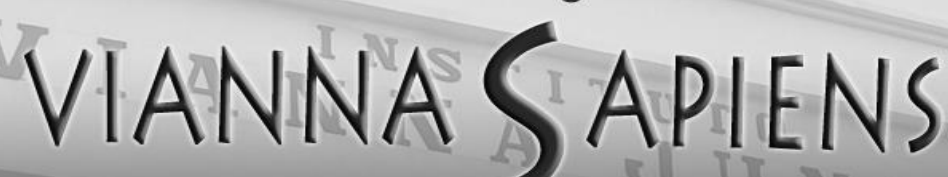

edição especial

Juiz de Fora - 2014

dade e irrevogabilidade das decisões judiciais transitadas em julgado. Não se pode olvidar que por se tratar de um princípio, não poderá ser colocado frente aos demais princípios existentes em nosso ordenamento jurídico, eis que os mesmos não podem ser sobrepostos a outros, mas sim aplicados de forma conjunta, com o intuito de melhor aplicação ao caso concreto.

Assim sendo, a relativização da coisa julgada deve ser entendida como medida excepcional, limitada às situações em que os bens jurídicos envolvidos sobreponham-se à exigência da estabilização das relações jurídicas, sob pena de serem desfiguradas as bases que norteiam nosso Estado Democrático de Direito.

\title{
FORCE THING FOUND IN OUR LAW AND ALGMAS CONSIDERATIONS SUCH INSTITUTE IN NEW CODE OF CIVIL PROCEDURE
}

\begin{abstract}
This work revolves around the institution of res judicata, which is provided in our Constitution (Article 5, XXXVI ) such as law and fundamental guarantee and is essential to the very existence of legal discourse and structural element of a democratic state. There is a huge divergence in doctrine about the relativity of res judicata, therefore, will be presented the main existing conflicting points, taking into account the mitigation of res judicata is an exception to the rule, occurring in exceptional cases. The force of res judicata in our legal system will be demonstrated . Leaving the legal provision that is deemed material thing undone by filing the reversal action of the same legal nature, your filing deadline, and in particular, their chances of appropriateness will be presented. Also discussed will be the institution of res judicata and the rescission action in the new Code of Civil Procedure project.
\end{abstract}

KEYWORDS : RES JUDICATA . LAW AND WARRANTY. LEGAL SECURITY . JUDICIAL DECISION . RESCISSION. 
Revista das Faculdades Integradas Vianna Júnior

\section{VIANNA SAPIENS}

edição e

Juiz de Fora

\section{REFERÊNCIAS}

BARINONI, Rodrigo. Alguns apontamentos sobre a ação rescisória no projeto do novo Código de Processo Civil. Brasília, ano 48, n. 190, abril/junho 2011. Disponível em:

<http:/www2.senado.leg.br/bdsf/bitstream/handle/id/242954/00094002.pdf?seque nce $=3>$. Acesso em 09/2013.

BRASIL. Constituição (1988). Constituição da República Federativa do Brasil. Brasília: DF: Senado, 1988.

BRASIL. Código de Processo Civil. 11. Ed. São Paulo: Rideel, 2012.

CÂMARA, Alexandre Freitas. Lições de Direito Processual Civil, vol. II. 18ํㅡ. Ed. Rio de Janeiro: Lúmem Júris, 2010.

CHIOVENDA, Giuseppe. Instituições de Direito Processual Civil, vol. I. 2º Ed. Campinas: Bookseller, 2000.

COSTA, Coqueijo. Ação Rescisória. 7º Ed. São Paulo: LTr, 2002.

DELLORE, Luiz. Da ampliação dos limites objetivos da coisa julgada no novo Código de Processo Civil. Brasília, ano 48, n. 190, abril/junho de 2011. Disponível em:

<http:/www2.senado.leg.br/bdsf/bitstream/handle/id/242942/000939981.pdf?sequ ence $=3>$. Acesso em 09/2013.

DIDIER JÚNIOR, Fredie; CUNHA, Leonardo José Carneiro da. Curso de Direito Processual Civil: Meios de Impugnação às Decisões Judiciais e Processo nos Tribunais, vol. 3․ 8aㅡ. Ed. Salvador: Jus Podivm, 2010.

DINAMARCO, Cândido Rangel. Relativizar a coisa julgada material, vol. IV. no 19. Porto Alegre: Revista Síntese de Direito Civil e Processual Civil, 2002.

DELGADO, José Augusto. Efeitos da Coisa Julgada e os Princípios Constitucionais: Coisa Julgada Inconstitucionais. Rio de Janeiro: América Jurídica, 2002.

DONADEL, Adriane. A Ação Rescisória no Direito Processual Civil Brasileiro. 2003. 316 f. Dissertação (Mestrado em Direito) - Pontifícia Universidade Católica do Rio Grande do Sul. Porto Alegre, 2003.

GRECO, FILHO, Vicente. Direito Processual Civil Brasileiro, vol. II. 14ª Ed. São Paulo: Saraiva, 2000. 
Revista das Faculdades Integradas Vianna Júnior

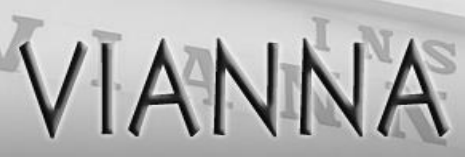

MAGRI, Berenice Soubhie Nogueira. Ação Anulatória: art. 486 do CPC. 2. Ed. São Paulo: Revista dos Tribunais, 2004

MARINONI, Luiz Guilherme. Coisa Julgada Inconstitucional: A retroatividades da decisão de (in) constitucionalidade do STF sobre a coisa julgada e a questão da relativização da coisa julgada. São Paulo: Editora Revista dos Tribunais, 2008.

MARINONI, Luiz Guilherme. Curso de Processo Civil: Teoria geral do processo, V. I. São Paulo: Editora Revista dos Tribunais, 2006.

MOREIRA, José Carlos Barbosa. Temas de Direito Processual. 9르 Ed. São Paulo: Saraiva, 2007.

MOREIRA, José Carlos Barbosa. Considerações sobre a causa de pedir na ação rescisória: Temas de direito processual. 4 Ed. São Paulo: Saraiva, 1989, p. 205.

NERY JUNIOR, Nelson; NERY, Rosa Maria Andrade. Código de Processo Civil comentado e legislação extravagante. 9ª Ed. São Paulo: RT, 2006.

RIZZATO, Rosana Tosti. Relativização da Coisa Julgada. Prática Jurídica, Brasília, ano XI, n. 125, p. 64-65, 08/2012.

SILVA, Ovídio Araújo Baptista da. Curso de Processo Civil: processo de conhecimento, V. I. 6ㅇ. Ed. Paulo: Revista dos Tribunais, 2002.

THEODORO JÚNIOR, Humberto. Curso de Direito Processual Civil, V. I. Rio de Janeiro: Forense, 2010. 